\title{
ANÚNCIO DE DESPEDIDA: poesia para Fernando
}

FAREWELL ANNOUNCEMENT: poetry for Fernando

Vagner Gonçalves da Silva*

Grande desvantagem para quem fica

É ter de anunciar aqueles que partem

E nos deixam sós lidando com o vazio

Que o amor verdadeiro lega

E que só se revela verdadeiro

Quanto mais ausente se faz.

Nesta tarde chuvosa em São Paulo

Fernando Brumana nos deixou.

Deixou o Brasil que ele tanto amava

O candomblé com seus deuses e formas

Um livro que sonha com os Dogon

Metáforas rompidas

O lado escuro das polaridades

Deixou também Santana e a Baia de Cádiz

A ver navios todos nós

Partiu hoje meu Dom Fernando

Amigo que me levou até a beira da Europa

E me lançou à África

Haverá uma varanda mais valiosa

Do que o coração de um amigo

Que nos abriga em dias de fúria

E nos convida a olhar o horizonte

Onde serenidade e estrelas se revezam

Após raios e tempestades?

Ter tido a honra de sentar à sua mesa

Posta nesta varanda

Me faz grande hoje

Mesmo que solitário sigo

buscando por este encantado que

Segue.... por onde já não mais alcanço...

* Antropólogo. E-mail: vagnergo@usp.br.

Foto: vista para África desde Cabo Branco/Paraíba/Brasil. 